\title{
GAMING COMMUNITY ARENA
}

\author{
Elizabeth Belinda ${ }^{1)}$, Agustinus Sutanto ${ }^{2)}$ \\ 1)Program Studi S1 Arsitektur, Fakultas Teknik, Universitas Tarumanagara, elizabethbells2222@gmail.com \\ 2)Program Studi S1 Arsitektur, Fakultas Teknik, Universitas Tarumanagara, gak.architects@gmail.com
}

\begin{abstract}
Abstrak
Generasi milenial hidup beriringan dengan perkembangan teknologi yang pesat. Berbeda dengan generasi sebelumnya, generasi ini lebih banyak menghabiskan waktu di dalam dunia maya daripada dunia nyata. Hiburan dunia maya seringkali menjadi solusi untuk melepas kepenatan dari kesibukan sehari-hari. Begitu pula dengan generasi milenial di Indonesia, dimana 56 persen dari mereka cenderung menghabiskan waktu untuk bermain video game. Adanya internet telah mengubah cara bermain yang satu arah menjadi tidak terbatas. Saat ini video game tidak hanya menjadi sarana hiburan, namun dapat menjadi sarana ajang kompetisi antar pemain. Sudah banyak generasi milenial yang menekuni industri permainan elektronik ini sebagai profesi yang menjanjikan. Namun, masih jarang tersedia wadah komunitas para pecinta game. Wadah yang tersedia hanya terbatas pada tempat penjualan / retail game tanpa ada sarana bermain video game dan fasilitas penunjangnya, seperti di kawasan pusat elektronik Glodok. Atau hanya menawarkan sarana bermain video game tanpa sarana penjualan dan penunjangnya, seperti Timezone. Di Indonesia, video game masih dipandang hanya sebagai hobi untuk mengisi waktu luang semata. Kurangnya dukungan pemerintah dan pandangan negatif masyarakat terhadap game juga menghambat terealisasinya proyek semacam ini. Dengan pertimbangan diatas, maka diharapakan arena komunitas gaming ini tidak hanya menjadi sarana hiburan, sosialisasi dan kompetisi, namun juga sebagai sarana pembelajaran dan pekerjaan dalam bidang game. Tujuan utama dari dari proyek kali ini adalah mewadahi komunitas sekaligus menjadi tempat kompetisi para percinta video game. Fasilitas permainan ini merupakan proyek bernilai komersial, yang terletak di daerah Jakarta barat, tepatnya kawasan Grogol Petamburan. Konsep yang dipakai pada bangunan terinspirasi dari papan motherboard yang merupakan inti penggerak dalam seluruh perangkat elektronik video game.
\end{abstract}

Kata kunci: milenial; hiburan dunia maya; komunitas; kompetisi; video game

\begin{abstract}
Millennials live in tandem with rapid technological development. Unlike the previous generation, this generation spends more time in cyberspace than the real world. Cyber entertainment often becomes the solution to relieve fatigue from daily activities. So is the millennial generation in Indonesia, where 56 percent of them tend to spend time playing video games. The existence of the internet has changed the way one play becomes unlimited. Currently video games are not only a means of entertainment, but can be a means of competition between players. There have been many millennials who have pursued the electronic game industry as a promising profession. However, there is still rarely a community forum for game lovers. The available containers are only limited to the place of sale / retail games without any means of playing video games and supporting facilities, such as in the Glodok electronic center. Or just offer a means to play video games without the means of sales and support, such as Timezone. In Indonesia, video games are still seen as mere hobbies for leisure time. Lack of government support and a negative public view of the game also impedes the realization of this kind of project. With the above considerations, hopefully the gaming community arena will not only be a means of entertainment, socialization and competition, but also as a means of learning and employment in the field of gaming. The main objective of the project this time is to accommodate the community as well as a place for competition for video game lovers. This game facility is a commercial value project, located in the West Jakarta area, precisely in the Grogol Petamburan area. The concept used in the building is inspired by the motherboard which is the driving core in all electronic video game devices.
\end{abstract}

Keywords: community; competition; cyber entertainment; millennials; video game 


\section{PENDAHULUAN}

\section{Latar Belakang Isu}

Pada era globalisasi ini, perkembangan teknologi berperan penting dalam percepatan hidup dan perubahan perilaku masyarakat. Kemajuan teknologi memberikan berbagai kemudahan melalui perangkat elektronik yang semakin canggih. Perangkat elektronik seakan-akan menjadi kebutuhan sehari-hari, mulai dari berkomunikasi, bermain, membuat makanan, belajar dan kebutuhan mendasar lainnya. Kemajuan teknologi juga memudahkan setiap individu untuk mengakses berbagai informasi dan berita secara real time. Melalui internet, semua orang dapat terhubung ke berbagai belahan dunia darimana pun dan kapan pun mereka inginkan, sehingga tidak ada lagi pembatas ruang dan waktu. Penggunaan internet setiap tahunnya semakin meningkat, bahkan dilansir dari lembaga riset pasar eMarketer, Indonesia menempati posisi keenam pengguna internet terbanyak di dunia dan mayoritas penggunanya merupakan generasi millennial.

\begin{tabular}{|c|c|c|c|c|c|c|}
\hline & 2013 & 2014 & 2015 & 2016 & 2017 & 2018 \\
\hline 1. China* & 620.7 & 643.6 & 669.8 & 700.1 & 736.2 & 777.0 \\
\hline 2. Us". & 246.0 & 252.9 & 259.3 & 264.9 & 269.7 & 274.1 \\
\hline 3. India & 167.2 & 215.6 & 252.3 & 283.8 & 313.8 & 346.3 \\
\hline 4. Brazil & 99.2 & 107.7 & 113.7 & 119.8 & 123.3 & 125.9 \\
\hline 5. Japan & 100.0 & 102.1 & 103.6 & 104.5 & 105.0 & 105.4 \\
\hline 6. Indonesia & 72.8 & 83.7 & 93.4 & 102.8 & 112.6 & 123.0 \\
\hline 7. Russia & 77.5 & 82.9 & 87.3 & 91.4 & 94.3 & 96.6 \\
\hline 8. Germany & 59.5 & 61.6 & 622 & 62.5 & 62.7 & 62.7 \\
\hline 9. Mexico & 53.1 & 59.4 & 65.1 & 70.7 & 75.7 & 80.4 \\
\hline 10. Nigeria & 51.8 & 57.7 & 63.2 & 69.1 & 76.2 & 84.3 \\
\hline 11. UK $\cdots$ & 48.8 & 50.1 & 51.3 & 52.4 & 53.4 & 543 \\
\hline 12. France & 48.8 & 49.7 & 50.5 & 51.2 & 51.9 & 52.5 \\
\hline 13. Philippines & 42.3 & 48.0 & 53.7 & 59.1 & 64.5 & 69.3 \\
\hline
\end{tabular}

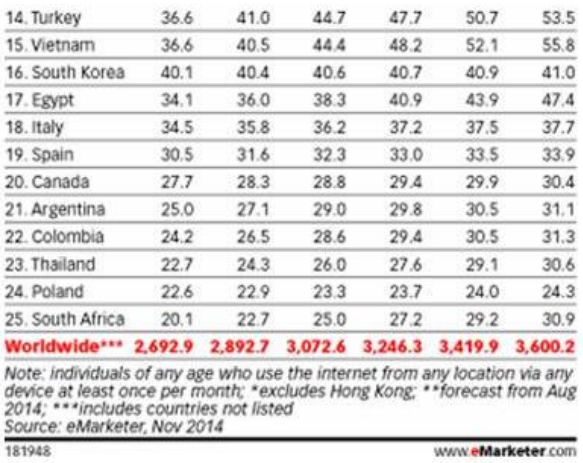

Gambar 1. Pengguna internet terbanyak berdasarkan negara Sumber: https://tekno.kompas.com/read/2014/11/24/07430087/ Pengguna.Internet.Indonesia.Nomor.Enam.Dunia

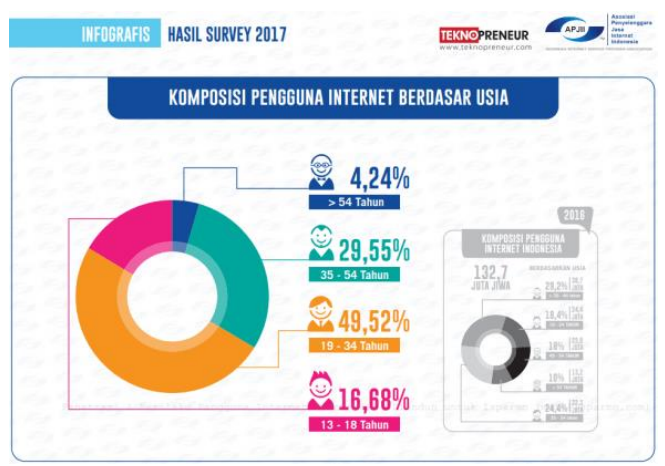

Gambar 2. Komposisi pengguna internet berdasarkan usia

Sumber: http://isparmo.web.id/2018/08/01/data-statistik-pengguna-internet-di-indonesia-2017berdasarkan-survey-apjii/

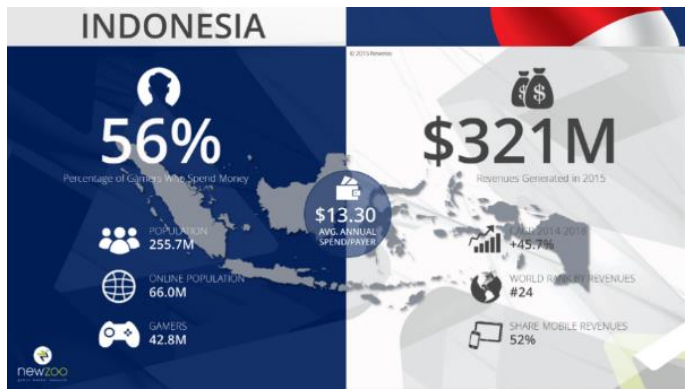

Gambar 3. Statistik industri game di Indonesia

Sumber: https://kominfo.go.id/content/detail/4286/pengguna-internet-indonesia-nomorenam-dunia/0/sorotan_media 
Salah satu penggunaan internet terbanyak kaum millennial adalah untuk bermain game/gaming. Hiburan dunia maya (cyber entertainment) seringkali menjadi solusi untuk melepas kepenatan dari kesibukan sehari-hari. 56 persen diantaranya bahkan merupakan pemain game yang rela mengahabiskan uangnya untuk bermain game/gaming. Bermain game/gaming yang dimaksud disini merupakan aktivitas bermain video game dengan menggunakan perangkat eletronik (Sumber: Cambridge dictionary). Cepatnya perkembangan industri game memberi pengaruh besar di Indonesia, seperti bertumbuhnya warnet-warnet di lingkungan perumahan, publisher game dan peminat game di kalangan millennial yang semakin banyak, produksi game local yang semakin banyak dan semakin canggih, dan munculnya atlet-atlet game professional. Dari perkembangan tersebut, mulai bermunculan berbagai komunitas para pecinta game secara global. Komunitas ini tidak hanya menjadi wadah untuk bermain, namun menjadi wadah sosialisasi dan ajang kompetisi. Bahkan beberapa pecinta game banyak yang menekuni kegiatan ini sebagai profesi yang dikategorikan sebagai e-sport. E-sport merupakan singkatan dari Electronic Sport, yang berarti : suatu kegiatan adu ketangkasan antar individu atau kelompok yang tidak terbatas hanya pada kegiatan fisik dan dilakukan dengan menggunakan peralatan- peralatan elektronik. (http://rezakudryavka.blogspot.com/2014/10/tugas-kuliah-all-aboutgame. html)

Di Indonesia, kegiatan bermain game masih dipandang negatif karena dianggap hanya menghabiskan waktu dan uang. Padahal sebenarnya bermain game dapat meningkatkan produktivitas kerja, mengajarkan bagaimana bias berpikir cepat dan strategis, bagaiman bekerja dalam satu tim, dan memperlambat penuaan otak. Kurangnya dukungan pemerintah dan pandangan negatif masyarakat terhadap game juga menghambat terealisasinya proyek semacam ini. Dengan pertimbangan diatas, maka diharapakan arena komunitas gaming ini tidak hanya menjadi sarana hiburan, sosialisasi dan kompetisi, namun juga sebagai sarana pembelajaran dan pekerjaan dalam bidang game.

\section{Identifikasi Masalah}

Adapun masalah yang dapat teridentifikasi dari latar belakang proyek ini antara lain adalah pandangan negatif akan kegiatan bermain game/gaming di kalangan masyarakat; belum adanya wadah khusus yang menaungi komunitas gaming generasi millennial secara fisik; minimnya sarana dan fasilitas untuk kompetisi gaming dalam skala yang cukup besar; dan tidak adanya kesinambungan antara retail tempat penjualan game, tempat bermain game, dan tempat pembuatan game.

\section{Rumusan Masalah}

Bagaimana cara memperkenalkan game pada masyarakat awam beserta potensi dari game itu sendiri?. Bagaimana cara menyusun program dan mendesain fasilitas agar ramai dikunjungi oleh pecinta game maupun yang tidak?. Bagaimana perilaku generasi millennial dapat mempengaruhi desain dan tipe yang ada?. Bagaimana desain dapat merepresentasikan gaming itu sendiri?.

\section{Tujuan dan Manfaat}

Menumbuhkan gairah masyarakat dalam gaming dan memperbaiki pandangan negatif yang ada; menciptakan suatu fasilitas yang sesuai perkembangan jaman (kesejamanan) saat ini sebagai hiburan untuk masyarakat millennial; menyediakan sebuah wadah khusus untuk berkumpul dan berkompetisi para pecinta game; menyediakan sebuah wadah untuk memperdalam pengetahuan maupun bekerja dalam dunia game.

\section{Gagasan Proyek}

Proyek yang diusulkan berdasarkan issue yang terjadi pada era generasi millennial ini, yaitu cyber entertainment. Proyek ini diharapkan dapat menjadi tempat untuk memperoleh hiburan-hiburan yang berkaitan dengan video game; berkumpul dan bersosialisasi untuk para pecinta game (komunitas); kompetisi dan menguji kemampuan kita dengan gamer lainnya; 
event-event yang berhubungan dengan video game; memperdalam sejarah dan cara pembuatan video game.

\section{Sustainable Development Goals}

Indonesia mulai menerapkan Tujuan Pembangunan Berkelanjutan (Sustainable Development Goals) dalam perencanaan pembangunan. Pemerintah telah mengambil tindakan awal dan menghubungkan sebagian besar indikator Tujuan Pembangunan Berkelanjutan ke dalam pembangunan Indonesia. Proyek ini juga diharapkan dapat mendukung pembangunan ini, dengan menerapkan nilai-nilai:

- Menciptakan wadah edukasi yang berkualitas

- Menciptakan kesetaraan gender

- Menciptakan pertumbuhan ekonomi dan memberikan pekerjaan yang layak

- Berperan dalam industri, inovasi dan infrasturktur

- Mengurangi kesenjangan

- Menciptakan komunitas dan perkotaan yang berkelanjutan
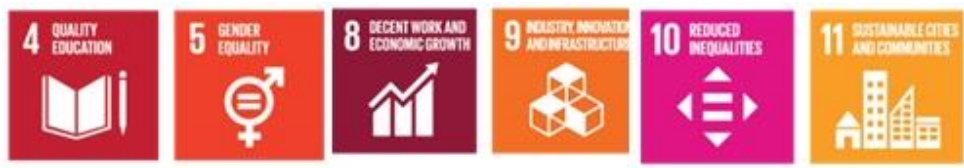

Gambar 4. Ikon Tujuan Pembangunan Berkelanjutan

Sumber: https://www.un.org/sustainabledevelopment/sustainable-development-goals/

\section{KAJIAN LITERATUR}

\section{Generasi Millennial}

Generasi milenial (juga dikenal sebagai Generasi Y) adalah generasi yang lahir antara awal tahun 1980an sampai awal tahun 2000an. Generasi Millennial menjadi topik penting dalam berbagai diskusi di dekade ini karena jumlah populasinya yang tengah berada di usia produktif dan memiliki jumlah terbesar secara global hingga saat ini. Generasi millennial juga memiliki tingkat pendidikan yang lebih tinggi dari generasi sebelumnya dan hidup dalam kondisi teknologi yang sudah maju. Sehingga millennial memiliki peran yang sangat signifikan dalam membawa perubahan dunia, termasuk dalam dunia arsitektur.

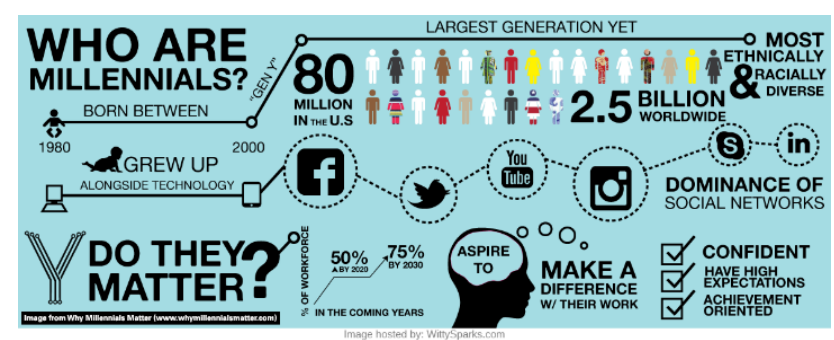

Gambar 5. Generasi millennial

Sumber: https://wittysparks.com/millennials-influencing-product-development/

Generasi milenial hidup beriringan dengan perkembangan teknologi yang pesat. Berbeda dengan generasi sebelumnya, generasi ini lebih banyak menghabiskan waktu di dalam dunia maya daripada dunia nyata. Hiburan dunia maya seringkali menjadi solusi untuk melepas kepenatan dari kesibukan sehari-hari. Begitu pula dengan generasi milenial di Indonesia, dimana 56 persen dari mereka cenderung menghabiskan waktu untuk bermain video game. Adanya internet telah mengubah cara bermain yang satu arah menjadi tidak terbatas. Saat ini video game tidak hanya menjadi sarana hiburan, namun dapat menjadi sarana ajang kompetisi antar pemain. Sudah banyak generasi milenial yang menekuni industri permainan elektronik ini sebagai profesi yang menjanjikan. Namun, masih jarang tersedia wadah komunitas para pecinta game. 


\section{Cyber Entertainment (Issue)}

Issue yang diambil didasarkan pada perilaku masyarakat generasi millennial yang banyak menghabiskan waktu di dunia maya. Hiburan dunia maya (cyber entertainment) seringkali menjadi solusi untuk melepas kepenatan dari kesibukan sehari-hari. 56 persen diantaranya bahkan merupakan pemain game yang rela mengahabiskan uangnya untuk bermain game/gaming. Cyber entertainment terdiri dari dua gabungan kata, yang mengandung arti:

- Cyber : dunia maya (Cambridge Dictionary)

- Entertainment : hiburan atau kesenangan (Cambridge Dictionary)

Sehingga dapat disimpulkan bahwa Cyber Entertainment adalah hiburan yang berhubungan dengan dunia maya.

\section{Game}

Dalam kamus bahasa Indonesia "Game" diartikan sebagai permainan. Permainan merupakan bagian dari bermain dan bermain juga bagian dari permainan keduanya saling berhubungan. Permainan adalah kegiatan yang kompleks yang didalamnya terdapat peraturan, play dan budaya. Sebuah permainan adalah sebuah sistem dimana pemain terlibat dalam konflik buatan, disini pemain berinteraksi dengan sistem dan konflik dalam permainan merupakan rekayasa atau buatan, dalam permainan terdapat peraturan yang bertujuan untuk membatasi perilaku pemain dan menentukan permainan. Game bertujuan untuk menghibur, biasanya game banyak disukai oleh anak - anak hingga orang dewasa. Games sebenarnya penting untuk perkembangan otak, untuk meningkatkan konsentrasi dan melatih untuk memecahkan masalah dengan tepat dan cepat karena dalam game terdapat berbagai konflik atau masalah yang menuntut kita untuk menyelesaikannya dengan cepat dan tepat. Tetapi game juga bisa merugikan karena apabila kita sudah kecanduan game kita akan lupa waktu dan akan mengganggu kegiatan atau aktifitas yang sedang kita lakukan. Game berasal dari kata bahasa inggris yang berarti dasar permainan. Permainan dalam hal ini merujuk pada pengertian kelincahan intelektual (Intellectual Playability Game) yang juga bisa diartikan sebagai arena keputusan dan aksi pemainnya. Dalam game, ada target-target yang ingin dicapai pemainnya.

\section{Jenis Game}

Berdasarkan jenis "platform" atau alat yang di gunakan :

1. Arcade games, yaitu yang sering disebut ding-dong di Indonesia, biasanya berada di daerah / tempat khusus dan memiliki box atau mesin yang memang khusus di design untuk jenis video games tertentu dan tidak jarang bahkan memiliki fitur yang dapat membuat pemainnya lebih merasa "masuk" dan "menikmati", seperti pistol, kursi khusus, sensor gerakan, sensor injakkan dan stir mobil (beserta transmisinya tentunya).

2. PC Games, yaitu video game yang dimainkan menggunakan Personal Computers..

3. Console games, yaitu video games yang dimainkan menggunakan console tertentu, seperti Playstation 2, Playstation 3, XBOX 360, dan Nintendo Wii..

4. Handheld games, yaitu yang dimainkan di console khusus video game yang dapat dibawa kemana-mana, contoh Nintendo DS dan Sony PSP..

5. Mobile games, yaitu yang dapat dimainkan atau khusus untuk mobile phone atau PDA..

Berdasarkan "genre" permainannya :

1. Aksi - Shooting, (tembak-tembakan, atau hajar-hajaran bisa juga tusuk-tusukan, tergantung cerita dan tokoh di dalamnya), video game jenis ini sangat memerlukan kecepatan refleks, koordinasi mata-tangan, juga timing, inti dari game jenis ini adalah tembak, tembak dan tembak. Termasuk didalam-nya :

a. First person shooting (FPS) seperti Counter Strike dan Call of Duty

b. Drive $n^{\prime}$ shoot, menggunakan unsur simulasi kendaraan tetapi tetap dengan tujuan utama menembak dan menghancurkan lawan, contoh : Spy Hunter, Rock and Roll Racing, Road Rash.

c. Shoot em' up, seperti Raiden, 1942, dan gradius. 
d. Beat 'em up (tonjok hajar) seperti Double Dragon dan Final Fight, lalu hack and slash (tusuk tebas) seperti Shinobi dan Legend of Kage.

e. Light gun shooting, yang menggunakan alat yang umumnya berbentuk seperti senjata, seperti Virtua Cop dan Time Crisis.

2. Fighting ( pertarungan) Ada yang mengelompokan video game fighting di bagian Aksi, namun penulis berpendapat berbeda, jenis ini memang memerlukan kecepatan refleks dan koordinasi mata-tangan, tetapi inti dari game ini adalah penguasaan jurus (hafal caranya dan lancar mengeksekusinya), pengenalan karakter dan timing sangatlah penting, o iya, combo-pun menjadi esensial untuk mengalahkan lawan secepat mungkin. Dan berbeda seperti game Aksi pada umumnya yang umumnya hanya melawan Artificial Intellegence atau istilah umumnya melawan komputer saja, pemain jenis fighting game ini baru teruji kemampuan sesungguhnya dengan melawan pemain lainnya. Seri Street Fighter, Tekken, Mortal Kombat, Soul Calibur dan King of Fighter adalah contohnya.

3. Aksi - Petualangan. Memasuki gua bawah tanah, melompati bebatuan di antara lahar, bergelayutan dari pohon satu ke pohon lain, bergulat dengan ular sambil mencari kunci untuk membuka pintu kuil legendaris, atau sekedar mencari telepon umum untuk mendapatkan misi berikutnya, itulah beberapa dari banyak hal yang karakter pemain harus lakukan dan lalui dalam video game jenis ini. Menurut penulis, game jenis ini sudah berkembang jauh hingga menjadi genre campuran action beat-em up juga, dan sekarang, di tahun 2000 an, jenis ini cenderung untuk memiliki visual 3D dan sudut pandang orang ke-tiga. Tomb Rider, Grand Theft Auto dan Prince of Persia termasuk didalamnya.

4. Petualangan. Bedanya dengan jenis video game aksi-petualangan, refleks dan kelihaian pemain dalam bergerak, berlari, melompat hingga memecut atau menembak tidak diperlukan di sini. Video Game murni petualangan lebih menekankan pada jalan cerita dan kemampuan berpikir pemain dalam menganalisa tempat secara visual, memecahkan teka-teki maupun menyimpulkan rangkaian peristiwa dan percakapan karakter hingga penggunaan benda-benda tepat pada tempat yang tepat. Termasuk didalamnya:

a. Petualangan dengan teks atau sistem tunjuk dan klik, contoh: Kings Quest, Space Quest, Heroes Quest, Monkey Island, Sam and Max,

b. Novel atau film interaktif, seperti game "dating" yang banyak beredar di jepang, Dragons Lair dan Night Trap.

5. Simulasi, Konstruksi dan manajemen. Video Game jenis ini seringkali menggambarkan dunia di dalamnya sedekat mungkin dengan dunia nyata dan memperhatikan dengan detil berbagai faktor. Dari mencari jodoh dan pekerjaan, membangun rumah, gedung hingga kota, mengatur pajak dan dana kota hingga keputusan memecat atau menambah karyawan. Dunia kehidupan rumah tangga sampai bisnis membangun konglomerasi, dari jualan limun pinggir jalan hingga membangun laboratorium cloning. Video Game jenis ini membuat pemain harus berpikir untuk mendirikan, membangun dan mengatasi masalah dengan menggunakan dana yang terbatas. Contoh: Sim City, The Sims, Tamagotchi.

6. Role Playing. Video game jenis ini sesuai dengan terjemahannya, bermain peran, memiliki penekanan pada tokoh/peran perwakilan pemain di dalam permainan, yang biasanya adalah tokoh utamanya, dimana seiring kita memainkannya, karakter tersebut dapat berubah dan berkembang ke arah yang diinginkan pemain ( biasanya menjadi semakin hebat, semakin kuat, semakin berpengaruh, dII) dalam berbagai parameter yang biasanya ditentukan dengan naiknya level, baik dari status kepintaran, kecepatan dan kekuatan karakter, senjata yang semakin sakti, ataupun jumlah teman maupun mahluk peliharaan.Secara kebudayaan, pengembang game Jepang biasanya membuat Role Playing Game (RPG) ke arah cerita linear yang diarahkan seolah karakter kita adalah tokoh dalam cerita itu, seperti Final Fantasy, Dragon Quest dan Xenogears. Sedangkan pengembang game RPG Eropa, cenderung membuat karakter kita bebas memilih jalan cerita sendiri secara non-linear, seperti Ultima, Never Winter Nights, baldurs gate, Elder Scroll, dan Fallout.

7. Strategi. Kebalikan dari video game jenis action yang berjalan cepat dan perlu refleks secepat 
kilat, video game jenis strategi, layaknya bermain catur, justru lebih memerlukan keahlian berpikir dan memutuskan setiap gerakan secara hati-hati dan terencana. Video game strategi biasanya memberikan pemain atas kendali tidak hanya satu orang tapi minimal sekelompok orang dengan berbagai jenis tipe kemampuan, sampai kendaraan, bahkan hingga pembangunan berbagai bangunan, pabrik dan pusal pelatihan tempur, tergantung dari tema ceritanya. Pemain game strategi melihat dari sudut pandang lebih meluas dan lebih kedepan dengan waktu permainan yang biasanya lebih lama dan santai dibandingkan game action. Unsur-unsur permainannya biasanya berkisar sekitar, prioritas pembangunan, peletakan pasukan, mencari dan memanfaatkan sumberdaya (uang, besi, kayu,minyak,dll), hingga ke pembelian dan peng-upgrade-an pasukan atau teknologi. Game jenis ini terbagi atas:

a. Real Time Strategy, game berjalan dalam waktu sebenarnya dan serentak antara semua pihak dan pemain harus memutuskan setiap langkah yang diambil saat itu juga berbarengan mungkin saat itu pihak lawan juga sedang mengeksekusi strateginya. Contoh: Starcraft, Warcraft, dan Command and Conquer.

b. Turn Based Strategy, game yang berjalan secara bergiliran, saat kita mengambil keputusan dan menggerakan pasukan, saat itu pihak lawan menunggu, begitu pula sebaliknya, layaknya catur. Contoh: Front Mission, Super robot wars, Final Fantasy tactics, Heroes of might and magic, Master of Orion.

Sebenarnya ada yang memilah lagi menjadi jenis tactical dan strategi, namun penulis cenderung untuk menggabungkannya karena perbedaannya hanya ada di masalah skala dan ke-kompleks-an dalam manajemen sumber daya-nya saja.

8. Puzzle. Video game jenis ini sesuai namanya berintikan mengenai pemecahan teka-teki, baik itu menyusun balok, menyamakan warna bola, memecahkan perhitungan matematika, melewati labirin, sampai mendorong-dorong kota masuk ke tempat yang seharusnya, itu semua termasuk dalam jenis ini. Sering pula permainan jenis ini adalah juga unsur permainan dalam video game petualangan maupun game edukasi. Tetris, Minesweeper, Bejeweled, Sokoban dan Bomberman.

9. Simulasi kendaraan. Video Game jenis ini memberikan pengalaman atau interaktifitas sedekat mungkin dengan kendaraan yang aslinya, muskipun terkadang kendaraan tersebut masih eksperimen atau bahkan fiktif, tapi ada penekanan khusus pada detil dan pengalaman realistik menggunakan kendaraan tersebut. Terbagi atas beberapa jenis:

a. Perang. Video game simulasi kendaraan yang sempat tenar di tahun 90-an ini mengajak pemain untuk menaiki kendaraan dan berperang melawan kendaraan lainnya. Dan kebanyakan diantaranya memiliki judul sama dengan nama kendaraannya. Contoh : Apache 64, Comanche, Abrams, YF-23, F-16 fighting eagle. Tetapi game kehidupan bajak laut seperti 'Pirates!' pun dapat dikategorikan disini.

b. Balapan. Dari namanya sudah jelas, siapa sampai duluan di garis finish dialah pemenangnya! Terkadang malah pemain dapat memilih kendaraan, mendandani, upgrade mesin bahkan mengecatnya. Contoh: Top Gear, Test Drive, Sega Rally Championship, Daytona, Grand Turismo, Need For Speed, Mario Cart, ManXTT.

c. Luar Angkasa. Walau masih dapat dikategorikan simulasi kendaraan perang, tetapi segala unsur fiksi ilmiah dan banyaknya judul yang beredar membuat subgenre ini pantas dikategorikan diluar simulasi kendaraan perang. Jenis ini memungkinkan pemain untuk menjelajah luar angkasa, berperang dengan mahluk alien, mendarat di planet antah berantah atau sekedar ingin merasakan bagaimana menjadi kapten di film fiksi ilmiah kesayangan kamu. Contoh: Wing Commander, Freelancer, Star Wars X-Wing, Star Wars Tie Fighter, dll.

d. Mecha. Pendapat bahwa hampir tidak ada orang yang terekspos oleh film robot jepang saat kecilnya tidak memimpikan ingin mengendalikan robot, memang sulit dibantah. Dipopulerkan oleh serial Mechwarrior oleh Activision, subgenre Simulasi Mecha ini memungkinkan pemainnya untuk mengendalikan robot dan menggunakannya untuk menghancurkan gedung, helikopter dan tentu saja robot lainnya. Contoh: Mechwarrior, 
Gundam Last war Chronicles, dan Armored Core.

10. Olahraga. Singkat padat jelas, bermain sport di PC atau konsol anda. Biasanya permainannya diusahakan serealistik mungkin walau kadang ada yang menambah unsur fiksi seperti NBA JAM. Contohnya pun jelas, Seri Winning Eleven, seri NBA, seri FIFA, John Madden NFL, Lakers vs Celtics, Tony hawk pro skater, dll.

\section{Kategori lain}

1. Multiplayer Online. Game yang lagi trend di Indonesia bahkan dunia,menjadi salah satu titik balik mengapa dunia game dan internet di Indonesia dapat berkembang. Dan karena dimainkan online dan dengan sistem pembayaran menggunakan voucher, pembajakan sudah tidak menjadi masalah lagi. Game yang dapat dimainkan secara bersamaan oleh lebih dari 2 orang (bahkan dapat mencapai puluhan ribu orang dalam satu waktu) membuat pemain dapat bermain bersama dalam satu dunia virtual dari sekedar chatting hingga membunuh naga bersama teman yang entah bermain di mana. Umumnya permainan tipe ini dimainkan di PC dan bertema RPG, walau ada juga yang bertema music atau action. Contoh: Ragnarok online, O2jam, World of Warcraft, Ayo Dance, Lineage, Rose online

2. Casual games. Sesuai namanya, game yang casual itu tidak kompleks, mainnya rileks dan sangat mudah untuk dipelajari ( bahkan cenderung langsung bisa dimainkan ). Jenis ini biasanya memerlukan spesifikasi komputer yang standar pada jamannya dan ukurannya tidak lebih dari $100 \mathrm{MB}$ karena biasanya dapat di download versi demo-nya di website resminya. Genre permainannya biasanya puzzle atau action sederhana dan umumnya dapat dimainkan hanya menggunakan mouse ( biasanya game lain menggunakan banyak tombol tergantung game-nya ). Contoh: Diner Dash, Sally Salon, Bejeweled, Zuma, Feeding Frenzy, Insaniquarium.

3. Edugames. Video Game jenis ini dibuat dengan tujuan spesifik sebagai alat pendidikan, entah untuk belajr mengenal warna untuk balita, mengenal huruf dan angka, matematika, sampai belajar bahasa asing. Developer yang membuatnya, harus memperhitungkan berbagai hal agar game ini benar-benar dapat mendidik, menambah pengetahuan dan meningkatkan ketrampilan yang memainkannya. Target segmentasi pemain harus pula disesuaikan dengan tingkat kesulitan dan design visual ataupun animasinya. Contoh edugames : Bobi Bola, Dora the explorer, Petualangan Billy dan Tracy.

4. Advergames. Sering mengunjungi website merek-merek kesayangan anda? Permen coklat M\&M, Coca-cola, Nike, A-Mild, atau Rexona? Anda pasti menemukan game-game yang dapat dimainkan lalu dapat anda beritahukan / mengundang langsung ke teman-teman anda. jenis game yang biasanya mudah dimainkan ini mengusung dan menampilkan produk atau brand mereka baik secara gamblang maupun tersembunyi. Di era tumbuhnya media-media baru berteknologi tinggi sekarang ini, dunia periklanan memang sudah tidak lagi terbatas pada TV, koran, majalah, billboard dan radio, video game sekarang telah menjadi sarana beriklan atau membangun brand-awareness yang efektif. Baik melalui internet maupun di mainkan di eventevent mereka, edugames terasa semakin dibutuhkan untuk menjaring calon konsumen bagi produk yang menggunakan advergames ini. Contoh produk di indonesia yang membuat advergames: A-Mild, Rexona teens, Axe.

\section{Sejarah Gaming}

Asal usul permainan video/video game terletak pada awal tabung sinar katoda berbasis pertahanan peluru kendali sistem pada akhir 1940-an. Program-program ini kemudian diadaptasi ke dalam permainan sederhana lainnya di era tahun 1950-an. Pada akhir 1950-an dan melalui tahun 1960-an, lebih banyak permainan komputer yang dikembangkan (kebanyakan di komputer mainframe), secara bertahap tingkat kecanggihan dan kompleksitasnya pu turut bertambah. Setelah periode ini, video game menyimpang ke berbagai platform: arcade, mainframe, konsol, pribadi komputer dan kemudian permainan genggam.

Perusahaan komersial pertama konsol permainan video adalah Computer Space pada 1971, yang meletakkan dasar bagi industri hiburan baru di akhir 1970-an di Amerika Serikat, Jepang, dan 
Eropa. tapi ini perusahaan tidak bertahan lama ini sebagian besar disebabkan oleh banjir dari video game yang datang ke pasar mengakibatkan keruntuhan total industri game konsol di seluruh dunia, akhirnya menggeser dominasi pasar dari Amerika Utara ke Jepang. Tapi inihanya mempengaruhi pasar game konsol, pasar game komputer sebagian besar tidak terpengaruh. Generasi selanjutnya dari konsol video game akan terus didominasi oleh perusahaan-perusahaan Jepang. Walaupun beberapa upaya akan dilakukan oleh Amerika Utara dan perusahaanperusahaan Eropa, generasi keempat konsol, usaha mereka pada akhirnya akan gagal. . Tidak sampai generasi keenam konsol permainan video akan non-perusahaan Jepang merilis sebuah sistem konsol sukses secara komersial. Pasar telah mengikuti jalan yang sama dengan beberapa kali gagal dilakukan oleh perusahaan-perusahaan Amerika yang semuanya gagal di luar beberapa keberhasilan terbatas dalam permainan elektronik genggam sejak dini. Saat ini hanya perusahaan-perusahaan Jepang memiliki sukses besar konsol game handheld, walaupun dalam beberapa tahun terakhir permainan genggam telah datang ke perangkat seperti ponsel dan PDA .

\section{- Generasi Pertama}

Generasi pertama konsol permainan video berlangsung dari tahun 1972, dengan rilis dari Magnavox Odyssey, hingga 1977, ketika "pong"-style produsen konsol meninggalkan pasar secara massal karena pengenalan dan keberhasilan mikroprosesor berbasis konsol.

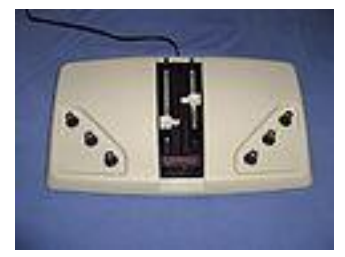

Gambar 6. Magnavox Odyssey 200

Sumber: https://g2hcombro.wordpress.com/sejarah-perkembangan-game/

\section{- Generasi kedua}

Dalam sejarah komputer dan video game, generasi kedua (biasa disebut sebagai awal era 8 bit atau kurang lebih 4 bit era) dimulai pada tahun 1976 dengan merilis Fairchild Channel $\mathrm{F}$ dan Radofin 1292 Advanced Programmable Video sistem. Di era generasi kedua ini yang menjadi primadona konsol game adalah konsol game ATARI. Beberapa contoh konsol game pada generasi kedua dapat dilihat disamping. Dari ki-ka adalah Fairchild Channel F,Atari 2600, Magnavox Odyssey ver. 2 , Atari 5200
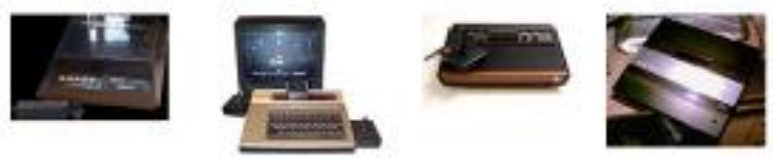

Gambar 7. Konsol generasi 2

Sumber : https://g2hcombro.wordpress.com/sejarah-perkembangan-game/

\section{- Generasi Ketiga}

Generasi ketiga dimulai pada tahun 1983 dengan dipasarkannya Jepang Family Computer tau lebih dikenal dengan nama FAMICOM(kemudian dikenal sebagai Nintendo Entertainment System di seluruh dunia). Walaupun konsol generasi sebelumnya juga menggunakan 8-bit processor, pada akhir generasi inilah konsol rumah yang pertama kali diberi label oleh mereka "bit". Ini juga masuk ke mode sebagai sistem 16-bit seperti Mega Drive / Genesis dipasarkan untuk membedakan antara generasi konsol. Di Amerika Serikat, generasi ini di game ini terutama didominasi oleh NES / Famicom. Di era ini pulalah terjadi perang konsol game yang pertama antara perusahaan konsol Nintendo dengan SEGA. 


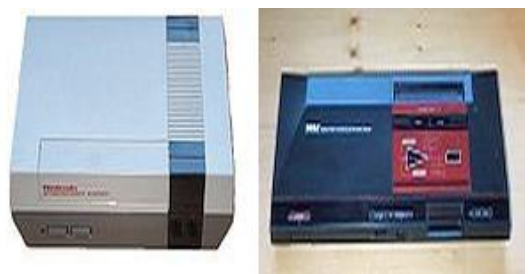

Gambar 8. Konsol FAMICOM dan SEGA

Sumber: https://g2hcombro.wordpress.com/sejarah-perkembangan-game/

- Generasi keempat

Generasi keempat atau biasa disebut dengan era 16 bit,pada generasi ini NES mendapat sambutan hangat di seluruh dunia, dan sebuah perusahaan bernama Sega mencoba menyaingi Nintendo. Pada tahun 1988, Sega merilis konsol next-generation mereka, Sega Mega Drive (yang juga dikenal dengan Sega Genesis). Konsol ini menyajikan gambar yang lebih tajam dan animasi yang lebih halus dibanding NES. Konsol ini cukup berhasil memberi tekanan, tetapi NES tetap bertahan dengan angka penjualan tinggi. Dua tahun berselang, pada 1990, Nintendo kembali menggebrak dengan konsol next-gen mereka, SNES (Super Nintendo Entertainment System). Selama 4 tahun, Nintendo dan Sega menjadi bebuyutan, meskipun ada beberapa produsen seperti SNK dengan NeoGeo-nya, NEC dengan TurboGrafx-16 dan Phillips CD-i, tapi kedua konsol mereka begitu handal dan populer.

- Tahun 1989

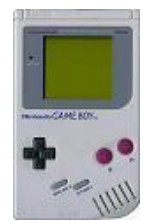

Gambar 9. Nintendo handheld pertama

Sumber: https://g2hcombro.wordpress.com/sejarah-perkembangan-game/

$\checkmark$ Nintendo merilis game-handheld, Game Boy. Harga: \$109.

$\checkmark$ NEC merilis video game sistem Turbografx-16, PC Engine versi Amerika Utara. Harga: \$189.

$\checkmark$ Sega merilis video game system Sega Genesis. Harga: \$249.

$\checkmark$ Atari merilis game-handheld berwarna pertama Atari Lynx. Harga: \$149.

$\checkmark$ NEC merilis versi yang ditingkatkan dari console PC Engine mereka di Jepang, SuperGrafx. Hanya 5 judul game yang memanfaatkan video game ini dan tidak pernah dijual secara komersial di luar Jepang.

- Tahun 1990

$\checkmark$ Trip Hawkins keluar dari Electronic Arts dan mendirikan 3DO.

$\checkmark$ NEC merilis Turbografx CD ekspansi untuk Turbografx-16, mengupgrade sistem tersebut dengan CD-ROM. Harga: \$399.

$\checkmark$ SNK merilis Neo-Geo (AES), untuk pertama kalinya sistem yang benar-benar membawa arcade ke rumah. Harga: $\$ 699$.

$\checkmark$ SquareSoft merilis Final Fantasy pertama yang nantinya menjadi role-playing game terbaik di sistem console.

$\checkmark$ Sega merilis game-handheld Game Gear.

$\checkmark$ Microprose terbentuk.

$\checkmark$ NEC merilis versi hanheld dari Turbografx-16 console mereka, TurboExpress.

- Tahun 1991

$\checkmark$ Commodore merilis video game rumahan berbasis CD, CDTV. Harga: \$999.

$\checkmark$ Fujitsu merilis FM Towns Marty, console 32-bit pertama di dunia. 
$\checkmark$ Nintendo merilis Super Nintendo. Harga: \$199.

$\checkmark$ Joe Santulli dan Kevin Oleniacz mendirikan Digital Press, publikasi independent kolektor video game berbagai sistem.

$\checkmark$ Dua penerbit PC entertaintment utama, Cinemaware dan Epyx, tutup.

- Tahun 1992

$\checkmark$ Philips merilis video game rumahan berbasis CD, CD-i.

$\checkmark$ Sega merilis ekspansi Sega CD untuk Sega Genesis.

- Generasi kelima

Generasi kelima atau disebut juga dengan era konsol 32 bit. dimana konsol game yang paling populer pada generasi ini adalah Sony Playstation

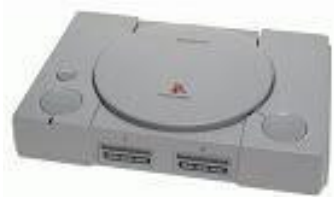

Gambar 10. Sony Playstation

Sumber: https://g2hcombro.wordpress.com/sejarah-perkembangan-game/

\section{- Generasi keenam}

Generasi keenam ini ditandai dengan munculnya konsol-konsol game next generation dari masing-masing perusahaan seperti SONY, SEGA,Nintendo serta munculnya satu lagi konsol game baru yang diluncurkan oleh Microsoft yang diberi nama Xbox. Perang konsol game ini akhirnya mengakibatkan jatuhnya perusahaan konsol SEGA yang tidak dapat lagi meneruskan konsol next generation (Dreamcast) mereka dan lebih memilih untuk berkonsentrasi dibidang pembuatan game konsol.

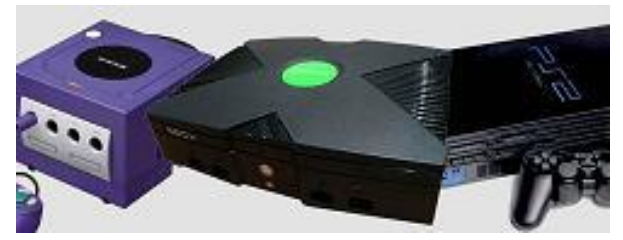

Gambar 11. Konsol game next generation dan Xbox

Sumber: https://g2hcombro.wordpress.com/sejarah-perkembangan-game/

- Generasi ketujuh

Dikarenakan semakin canggihnya teknologi di bidang teknologi maka kemudian 3 perusahaan konsol terbesar(Sony, Nintendo, dan Microsoft) mengeluarkan kembali konsol next-generation mereka keluaran terbaru. Sony mengeluarkan konsol next-gen yang diberi nama PS3(Playstation 3), lalu Nintendo dengan Nintendo Wii kemudian Microsoft dengan Xbox 360. Pada generasi ini semakin dikembangkan sistem permainan online atau permainan yang melibatkan banyak pemain yang terhubung dengan konsol mereka dan semakin ditinggalkannya permainan single player.

\section{Dampak gaming}

Dampak Positif :

$\checkmark$ Melalui jaringan internet, memungkinkan pemain untuk melakukan sosialisasi virtual tanpa dibatasi ruang dan waktu. Bukan hal langka lagi ketika seorang pemain permainan daring menjalin hubungan pertemanan bahkan pernikahan yang bermula dari bermain game online bersama.

$\checkmark$ Permainan daring seringkali menuntut pemainnya untuk menyusun strategi dalam waktu singkat sehingga permainan yang tepat dapat melatih respon dan kecepatan berpikir seseorang. Hasil penelitian University of Rochester di New York, Amerika menyebutkan bahwa 
para pemain memiliki fokus yang lebih terhadap apa yang terjadi di sekelilingnya, jika dibandingkan dengan mereka-mereka yang jarang main game, apalagi yang tidak main sama sekali.

$\checkmark$ Permainan daring jika dimanfaatkan dapat membuka peluang bisnis dan lahan mandapatkan penghasilan tambahan. Misalnya saja dengan menjadi pengusaha game centre, berjualan voucher permainan, atau bahkan melakukan transaksi jual beli melalui permainan.

Dampak Negatif :

$\checkmark$ Sosialisasi fisik berkurang, karena pemain lebih banyak menghabiskan waktu untuk bersosialisasi di dunia maya.

$\checkmark$ Permainan daring dimainkan melalui komputer, yang mengeluarkan spektrum cahaya yang dapat merusak mata jika dipandangi terus-menerus tanpa istirahat.

$\checkmark$ Beberapa permainan daring memerlukan biaya untuk memainkannya, misalnya dalam kategori permainan pay-to-play atau sekadar biaya penyewaan komputer di warnet atau game centre. Apabila tidak diorganisir dengan baik, permainan daring dapat menghabiskan biaya cukup besar.

$\checkmark$ Permainan daring dapat mengacaukan manajemen waktu jika tidak diatur dengan baik. Banyak kasus di mana pemain yang kecanduan permainan daring bermain hingga lupa waktu dan melalaikan segala tanggung jawab dan pekerjaannya di dunia nyata, seperti bolos sekolah.

$\checkmark$ Dalam beberapa kasus, pemain sama sekali melupakan aktivitas fisik dan makan di dunia nyata selama berhari-hari sehingga menimbulkan serangan jantung dan kematian.

$\checkmark$ Pikiran akan selalu terarah pada game dan berakibat berkurangnya konsentrasi untuk belajar.

$\checkmark$ Emosi tidak stabil.

\section{METODE}

\section{Metode Penelitian}

Metode penelitian yang digunakan adalah penelitian deskriptif. Penelitian deskriptif, menurut Suryana (2010), adalah metode yang digunakan untuk mencari unsur-unsur, ciri-ciri, sifat-sifat suatu fenomena. Metode yang digunakan dengan cara pengumpulan data sebagai berikut :

1. Data

Mencari unsur-unsur dari Generasi Millennial, seperti gaya hidup dan perilakunya, dan fenomena issue yang muncul. Data - data statistik digunakan dalam menganalisa kebutuhan dan juga menentukan program yang tepat untuk menjawab fenomena issue.

2. Observasi

Observasi dilakukan untuk memilih dan menganalisis kawasan lingkungan yang cocok untuk menjadi lokasi proyek bagi Generasi Millennial.

3. Kajian

Kajian dari studi preseden didapatkan untuk menentukan besaran dan luas program ruang, serta studi tipologi.

4. Mapping

Metode ini digunakan dalam analisa makro untuk melihat kota secara keseluruhan dari segi radius pelayanan, jarak, zonasi, dan lain - lain.

Dilihat dari perkembangan teknologi Informasi dan Komunikasi yang ada di seluruh dunia, Jakarta memiliki potensi dalam mengembangkan permainan elektronik yang ada saat ini. Tingginya angka pengguna aktif internet di Jakarta juga turut menjadi alasan mengapa Jakarta menjadi lokasi yang cocok.

\section{Metode Perancangan}

Metode perancangan yang digunakan adalah tipologi. Tipologi adalah suatu studi yang berkaitan dengan tipe dari beberapa objek yang memiliki jenis yang sama. Tipologi merupakan sebuah bidang studi yang mengklasifikasikan, mengkelaskan, mengelompokkan objek dengan ciri khas struktur formal yang sama dan kesamaan sifat dasar ke dalam tipe-tipe tertentu dengan cara memilah bentuk keragaman dan kesamaan jenis. Aspek klasifikasi dalam pengenalan tipologi 
mengarah pada usaha untuk mengklasifikasikan, mengkelaskan, mengelompokkan objek berdasarkan aspek-aspek/kaidah-kaidah tertentu. Aspek-aspek yang dapat diklasifikasikan dapat berupa fungsi, bentuk, maupun gaya. Tipologi merupakan ilmu yang mempelajari segala sesuatu yang berkaitan dengan tipe. Arti kata 'tipe' sendiri berasal dari bahasa Yunani typos yang berarti 'the root of...', atau dalam bahasa Indonesia diartikan sebagai 'akar dari...'(Loekito, 1994). Moneo (1976) dalam Loekito (1994), secara konsepsional mendefinisikan tipologi sebagai sebuah konsep yang mendeskripsikan sebuah kelompok obyek atas dasar kesamaan karakter bentuk-bentuk dasarnya.

Amiuza (2006) dalam kajiannya mengatakan, tipologi merupakan suatu konsep mendeskripsikan kelompok objek berdasarkan atas kesamaan sifat-sifat dasar yang berusaha memilah atau mengklasifikasikan bentuk keragaman dan kesamaan jenis. Dalam hal ini, tipologi merupakan hasil elaborasi karakteristik arsitektur, yang tersusun dari berbagai unsur kultural lokal dan luar yang spesifik dalam suatu struktur klasifikasi, baik secara klasifikasi fungsi, geometrik, maupun langgam/gaya. Secara umum, tipologi berlandaskan pada kemungkinan mengelompokkan beberapa objek, karena memiliki kesamaan dalam sifat-sifat dasarnya. Tipologi juga dapat diartikan sebagai sebuah tindakan berpikir dalam rangka pengelompokan (Loekito 1994). Pada awal mulanya, tipologi sering disalah artikan sebagai sebuh cara melakukan klasifikasi atas dasar kriteria 'model'. Kata 'tipe' menggambarkan sesuatu yang bersifat spesifik, dan tidak dapat diulang, sedangkan kata 'model' berarti sesuatu yang ada atau hadir karena akan diulang (Loekito 1994).

Tipologi adalah studi tetang tipe. Tipe adalah kelompok dari objek yang dicirikan oleh struktur formal yang sama, sehingga tipologi dikatakan sebagai studi tentang pengelompokkan objek sebagai model melalui kesamaan struktur. Struktur formal yang dimaksud disini tidak hanya berupa istilah yang berkaitan dengan geometrik fisik semata, tetapi berkaitan dengan apa yang disebut sebagai 'deeper geometry', yaitu geometri yang tidak hanya sebatas pada perbandingan geometri matematis, akan tetapi berkaitan dengan realita mulai dari aktivitas sosial sampai dengan konstruksi bangunan. Struktur formal juga diartikan sebagai kaitan atau inter-relasi antar elemen (Sugini dalam Aplikawati 2006). Tjahjono (1992) mengatakan bahwa studi tipologi dalam dunia arsitektur berarti studi dalam usaha pemilahan, klasifikasi, hingga dapat terungkap keragaman dan kesamaan dalam produk arsitektur yang satu dengan yang lainnya. Pada dasarnya, tipologi merupakan konsep yang mendeskripsikan kelompok objek atas dasar kesamaan sifat-sifat dasar. Menurut Sukada dalam Sulistijowati (1991), ada - tahapan yang harus ditempuh untuk menentukan suatu tipologi, yaitu sebagai berikut:

$\checkmark$ Menentukan bentuk-bentuk dasar yang ada pada setiap objek dasar arsitektural, yaitu kategori dan klasifikasi dari massing, denah, dan tampak.

$\checkmark$ Menentukan sifat-sifat dasar yang dimiliki oleh setiap objek arsitektural berdasarkan bentuk dasar yang ada dan melekat pada objek arsitektural, seperti pemakaian material, sirkulasi dalam bangunan, bentukan keruangan dan hubungan keruangan.

$\checkmark$ Mempelajari proses perkembangan bentuk dasar tersebut sampai pada perwujudannya saat ini. Masuknya unsur digitalisasi sebagai bentuk perkembangan jaman hingga pengaruhnya terhadap desain.

\section{DISKUSI DAN HASIL}

\section{Program}

Progam yang diusulkan berdasarkan issue yang terjadi pada era generasi millennial ini, yaitu hiburan dunia maya (cyber entertainment). 56 persen dari generasi millennial di Indonesia merupakan pemain game yang rela mengahabiskan uangnya untuk bermain game/gaming. Sehingga Program ini memiliki potemsi yang tinggi untuk berkembang. Progam ini memiliki judul Arena Komunitas Gaming (Gaming Community Arena). Arena Komunitas Gaming ini merupakan wadah komunitas dan kompetisi bagi para pecinta game, yang disertai dengan berbagai fasilitas penunjang. Fasilitas penunjang tersebut antara lain event space, retail, gaming historic gallery, 
dan gaming working space. Sasaran utama dari program ini adalah masyarakat berusia muda dan dewasa (generasi millennial) yang kebanyakan merupakan pelajar dan mahasiswa, dan pekerja.

Program-program yang ada pada bangunan akan disatukan ke dalam suatu aplikasi sehingga dapat diapantau secara live dan terhubung satu sama lain. Program dibagi menjadi beberapa kelompok yaitu :

1) Event space : merupakan program yang berfungsi sebagai tempat diadakannya acara dan kompetisi game secara berkala

2) Community space : merupakan program yang berfungsi sebagai tempat berkumpul dan bermain para pecinta game

3) Learning space : merupakan program yang berfungsi sebagai tempat belajar tentang dunia game lebih dalam ataupun berlatih untuk kompetisi game

4) Working space : merupakan program yang berfungsi sebagai tempat pembuatan game

5) Retail space : merupakan program yang berfungsi sebagai tempat berjualan makanan dan halhal seputar game.

\section{ACTIVITY TARGET}
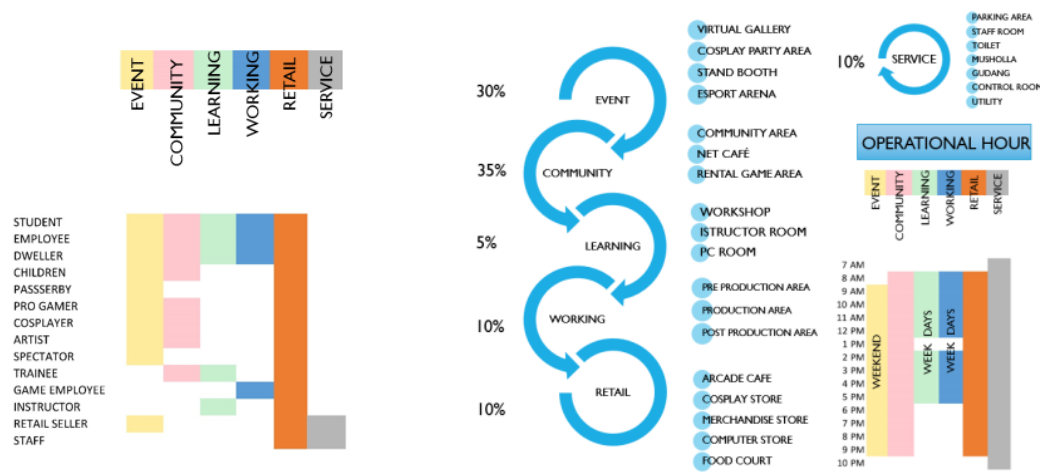

Gambar 12. Sasaran target aktvitas program; Program dan waktu operasional Sumber: Penulis, 2019

Agar arus kepadatan pengunjung dapat terdistribusi dengan baik, maka acara event yang berskala besar akan dibedakan jam operasionalnya dari program learning dan working yang membutuhkan ketenangan. Event, community, dan retail akan dipisah secara pembagian zoning agar tidak saling mengganggu satu sama lain.

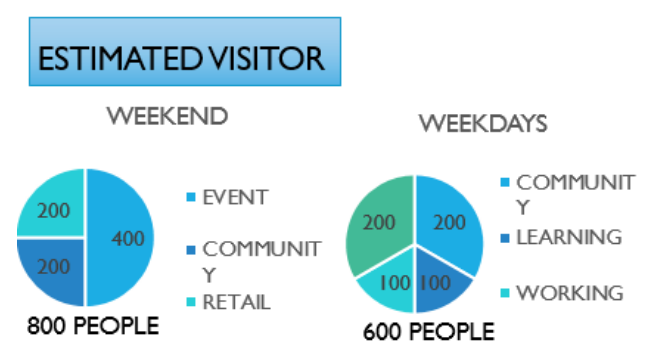

Lokasi Site

Gambar 13. Perkiraan jumlah pengunjung Sumber: Penulis, 2019

Saat ini, dukungan pemerintah Indonesia masih kurang akan industri game dan dianggap negatif oleh sebagian besar masyarakat. Padahal 56 persen dari generasi milenial di Indonesia cenderung menghabiskan waktu untuk bermain video game. Proyek ini diharapkan dapat berkontribusi dalam pengembangan industri game di Indonesia dan memunculkan potensipotensi di dalamnya, tidak hanya sebagai hiburan namun dapat menjadi wadah sosial, berkompetisi, bekerja dan belajar bagi para penikmatnya. 
Pertama-tama, kita mulai melihat kepada daerah-daerah yang memiliki potensi terhadap penggunaan internet terbanyak. Dari gambar di atas, dapat disimpulkan bahwa daerah ibukota Jakarta merupakan daerah penggunaan internet terbanyak.

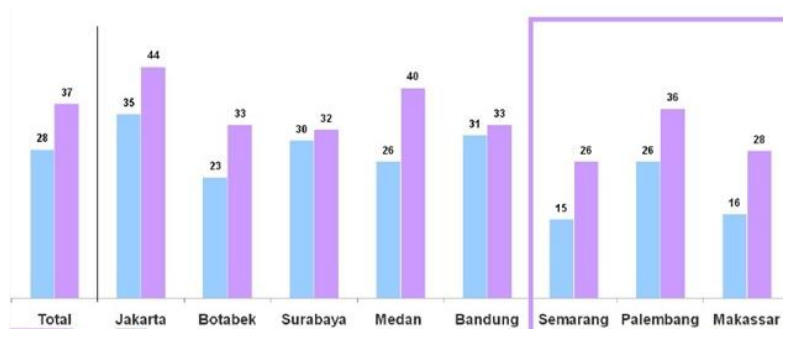

Gambar 14. Perbandingan penggunaan Internet di Indonesia Sumber: http://ratihsubagyo.blogspot.com/2011/01/pengguna-internet-di-indonesia.html

Lalu kita mulai memetakan komunitas game dan game center yang ada untuk mengetahui laju pertumbuhannya di setiap kawasan Jakarta. Diketahui bahwa daerah Jakarta Barat memiliki fasilitas internet café ataupun warung internet (warnet) terbanyak.

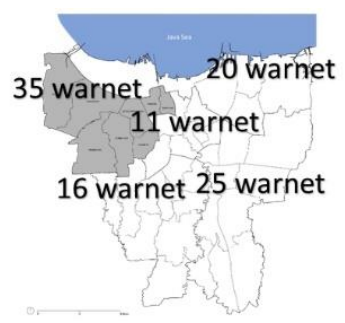

Gambar 15. Jumlah Internet café dan warnet di Jakarta Sumber: Penulis, 2019

Dua game developer terbesar di Indonesia, yaitu LYTOGAME dan PT.Garena juga menjadikan Jakarta Barat sebagai lokasi markas mereka. Sehingga daerah Jakarta Barat dianggap memiliki potensi yang tinggi untuk perkembangan gaming yang ada. Setelah menentukan Jakarta Barat sebagai image daerah gaming, kita mulai melihat kriteria-kriteria lain yang dapat berkontribusi dalam pengembangan proyek. Daerah Grogol Petamburan dipilih dikarenakan berada di kawasan dengan konsentrasi fasilitas pendidikan tertinggi sebagai sasaran pengunjung proyek (pelajar dan mahasiswa). Kawasan ini juga memiliki banyak proyek pendukung, seperti perumahan, apartemen, perkantoran dan pusat perbelanjaan, Selain itu, lokasi dekat dengan pusat pemasok elektronik, yaitu roxy Square dan berada di jalur utama arus pulang pergi para pekerja kaum millennial.

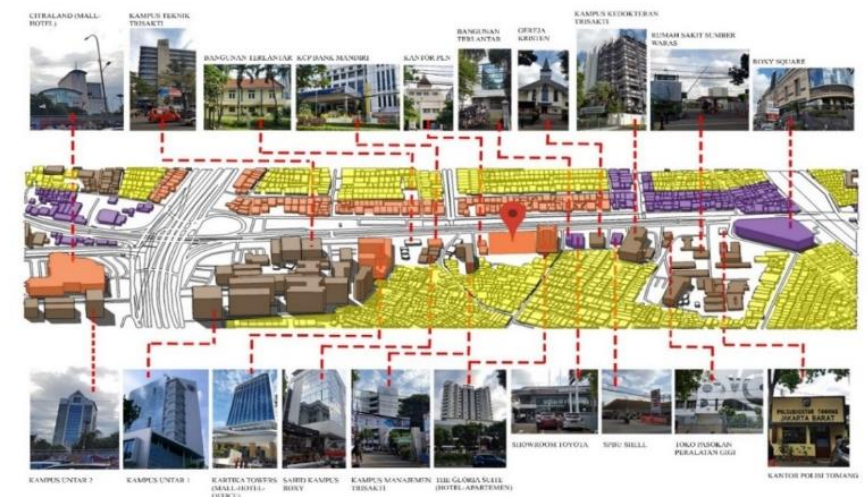

Gambar 16. Pemetaan bangunan sekitar tapak dan Zonasi Sumber: Penulis, 2019 
Lokasi dipilih di jalan arteri dan dekat dengan moda angkutan umum, dikarenakan fungsinya yang komersial sehingga harus strategis dan mudah dijangkau. Selain itu dipilihlah lokasi yang memiliki peruntukan campuran.

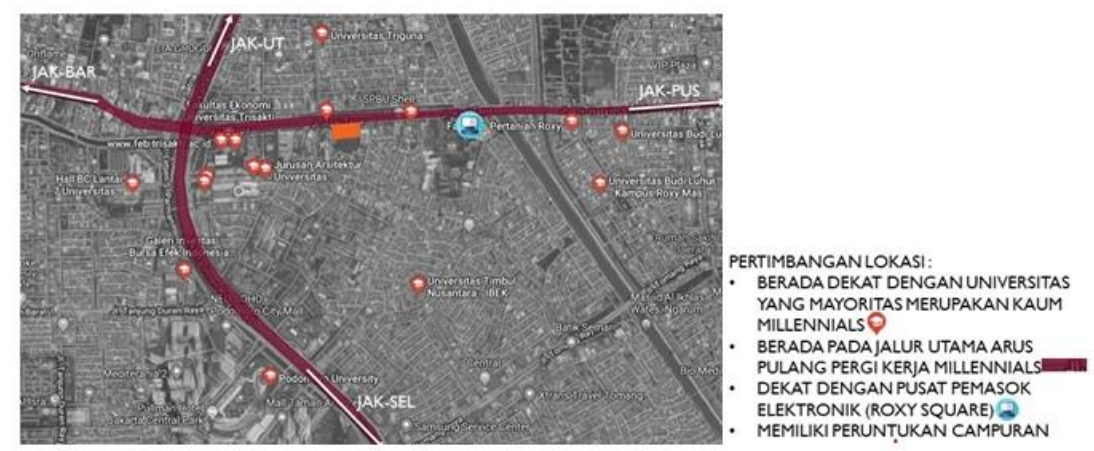

Gambar 17. Pertimbangan lokasi

Sumber: Penulis, 2019

Tapak terpilih berada di Jalan Kyai Tapa, Tomang dengan lebar jalan di mukanya berkisar 10 meter. Memiiliki spefikasi berupa luas tapak 5910m2; KDB 60\%; KLB 3,5; KDH 30; KTB 55; KB 8
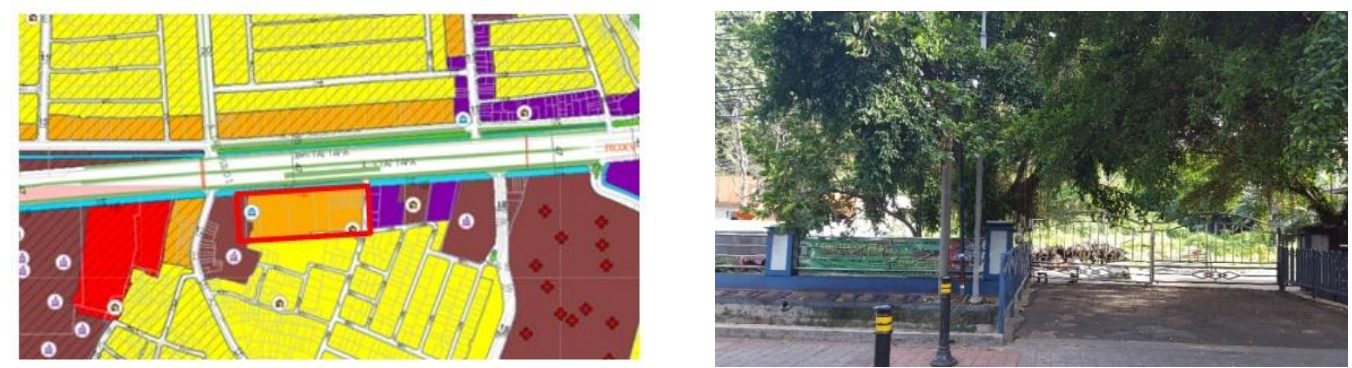

Gambar 18. Zonasi tapak dan foto eksisting tapak

Sumber: http://smartcity.jakarta.go.id/maps/ dan dokumen pribadi

Tapak eksisting berupa lahan kosong yang tidak terpakai. Dulunya merupakan bangunan sarana pendidikan yang kemudian pindah dan dihancurkan. Proyek yang dibangun diharapkan dapat mengubah image tapak yang mati dan tersingkirkan.

\section{Analisa Tapak}

Tapak sangat strategis karena berada di Jalan Kyai Tapa yang merupakan daerah transit untuk angkutan umum. Terdapat 3 jenis moda angkutan umum yang berada tidak jauh dari tapak, yaitu busway, bis, dan kereta. Moda angkutan terdekat adalah halte busway RS Sumber Waras yang hanya berjarak 100 meter dari tapak. Sehingga tapak dapat dengan mudah diakses oleh para pejalan kaki (pedestrian) yang menggunakan angkutan umum, ataupun orang-orang sekitar yang menjadi sasaran target dalam proyek (pelajar dan mahasiswa). Selain itu, Jalan Kyai Tapa juga merupakan jalur utama arus pulang pergi para pekerja millennial. Lokasinya yang berada di jalan arteri juga memudahkan para pengguna mobil dan motor untuk dapat mengakses tapak. 


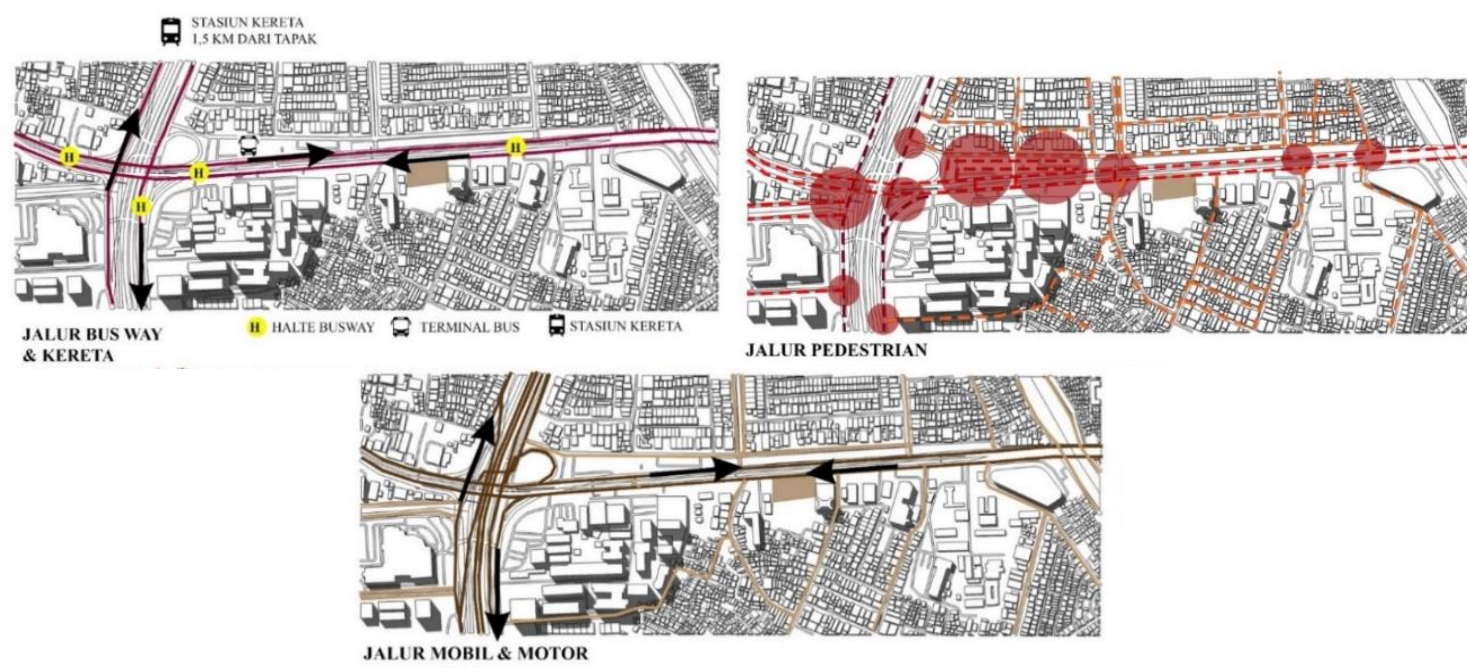

Gambar 19. Pemetaan jalur kendaraan dan pedetrian Sumber: Penulis, 2019

Dari pemetaan jalur kendaraan dan pedestrian yang ada maka dapat disimpulkan bahwa focal point sekaligus titik ramai berada di perempatan Grogol. Sehingga berada berlawanan arah dengan arus kendaraan pada jalan muka tapak.

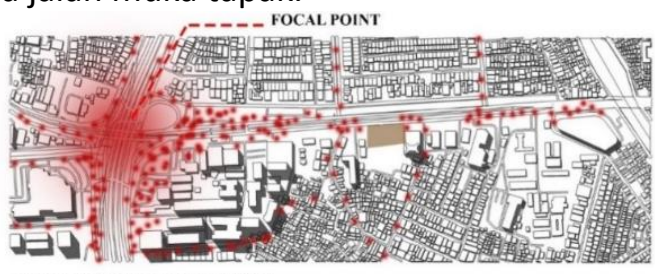

JALUR PERGERAKAN AKTIVITAS

Gambar 20. Pemetaan jalur pergerakan aktivitas Sumber: Penulis, 2019

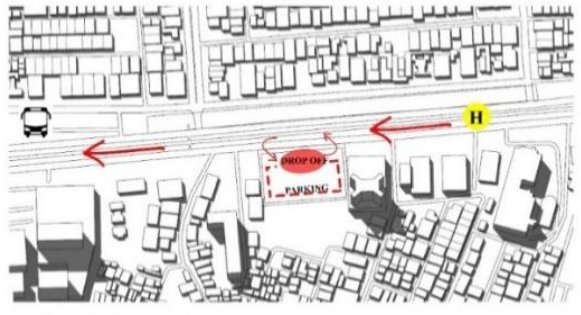

ENTRANCE KENDARAN

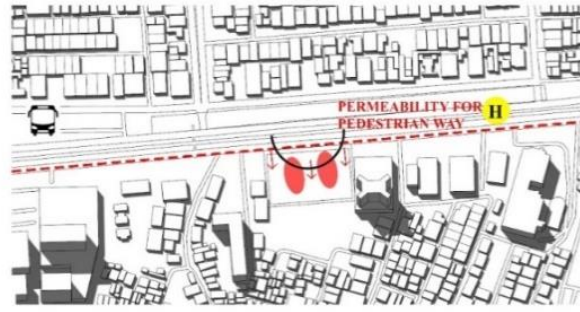

ENTRANCE PEDESTRLA

Gambar 21. Analisa sirkulasi dalam tapak Sumber: Penulis, 2019

Dari pemetaan jalur kendaraan yang ada dapat diusulkan untuk pembuatan drop off pada bagian depan tapak untuk kendaraan yang singgah sementara dan pembuatan jalur sirkulasi yang saling terhubung (permeability) dalam tapak bagi para pejalan kaki. Sisi panjang tapak menghadap ke utara dan selatan hanya sedikit menerima panas matahari pagi dan sore. Sisi Timur Tapak juga menerima lebih sedikit panas matahari pagi dikarenakan sinar matahari terhalang tower apartemen di sampingnya. Untuk bagian tapak yang terkena sinar matahari sore dapat ditanami vegetasi maupun menggunakan material penutup bangunan yang dapat mereduksi panas sinar matahari. 


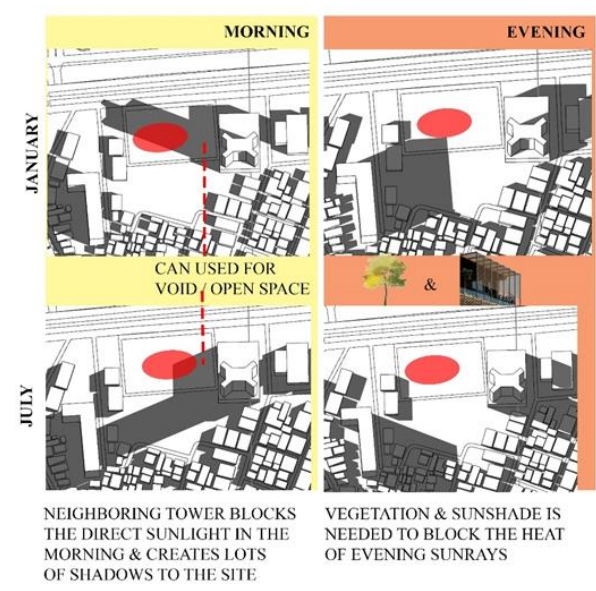

Gambar 22. Pencahayaan pada tapak Sumber: Penulis, 2019

Kawasan Tapak dikelilingi dengan bangunan sekitar yang mempunyai perbedaan ketinggian yang cukup signifikan. Tapak menjadi transisi antara bangunan tinggi (tower) dan bangunan rendah (2-4 lantai). Desain bangunan disesuaikan dengan skyline dan ketinggian bangunan disekitarnya.

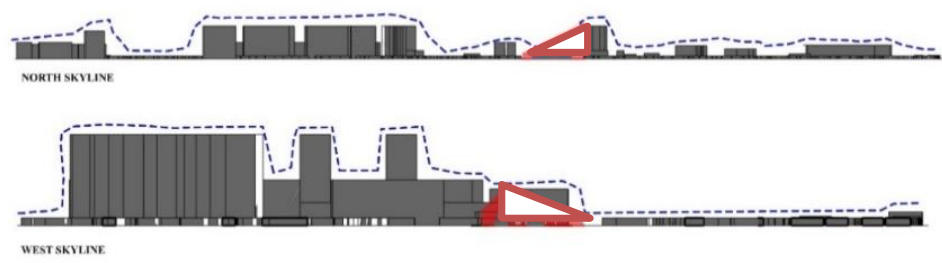

Gambar 23. Potongan Kawasan

Sumber: Penulis, 2019

Tapak berada di kawasan perkotaan yang cukup padat dengan berbagai hiru pikuknya. Tidak ada view yang menarik di sekitar tapak mengakibatkan perlu adanya pembuatan view yang menarik dalam tapak.

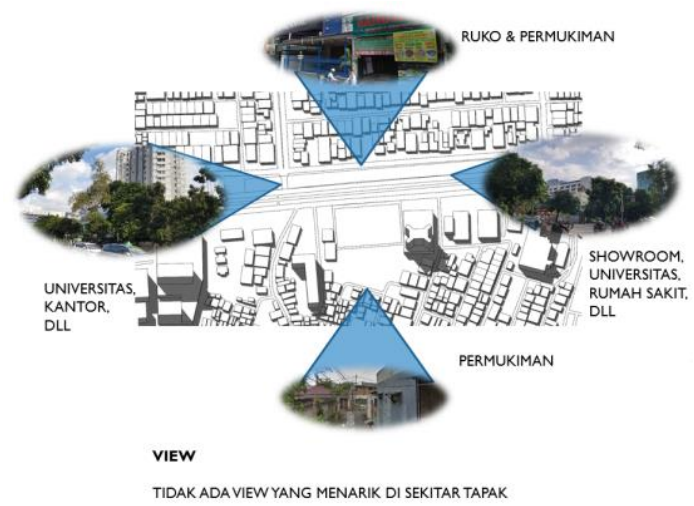

Gambar 24. View tapak

Sumber: Penulis, 2019

View dapat berupa taman maupun atraksi yang berhubungan dengan gaming, misalnya gambaran visualisasi melalui media elektronik seperti led screen. Fungsi bangunan sebagai komunitas dan arena gaming juga tidak terlepas dari seni yang dapat dilihat di film animasi, tokoh game dan komik, dan sebagainya. Seni tersebut dapat dipublikasikan melalui outdoor gallery, miniature, sculpture dan lainnya. 

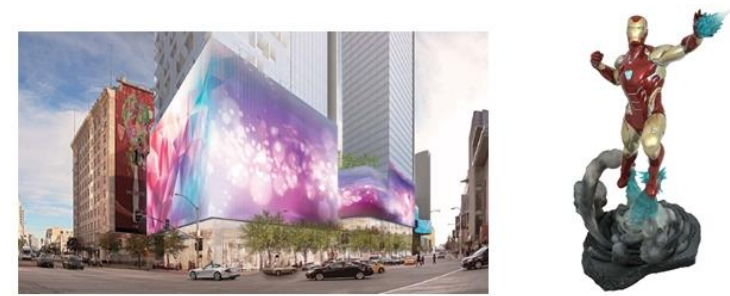

Gambar 25. Atraksi gaming

Sumber : https://skyrisecities.com/news/2016/09/updated-w-hotel-los-angeles-proposal-features-massivewrap-around-led-screen, https://forbiddenplanet.com/catalog/toys-collectibles/statues-busts/?page=1

\section{Konsep dan Gubahan Massa}

Penerapan Tema

Konsep terinsipirasi dari papan motherboard yang merupakan inti penggerak dari smua jenis peralatan elektronik gaming. Area motherboard dibagi menjadi 2 bagian yaitu, bagian inti dan pelengkap, yang nantinya akan digunakan untuk merepresentasikan pembagian zona dalam bangunan.

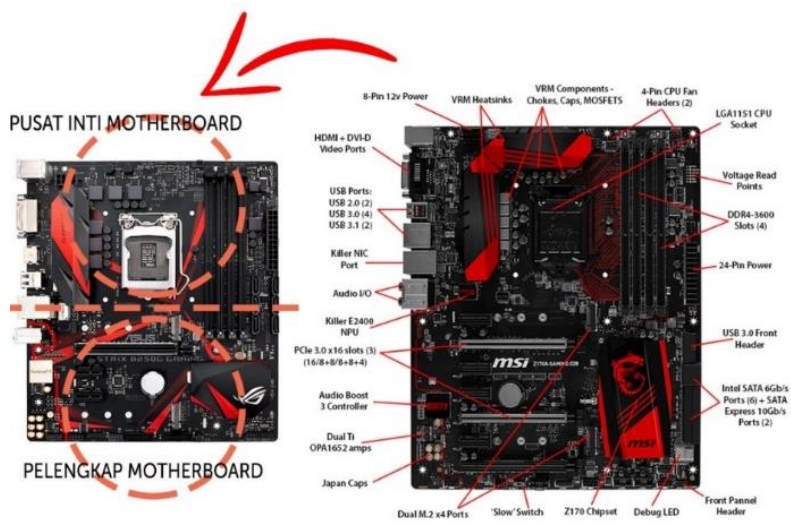

Gambar 26. Bagian dari motherboard

Sumber : http://kkomputer.com/ , https://www.hardwarecanucks.com/forum/hardware-canucksreviews/70201-msi-z170a-gaming-m5-motherboard-review-3.html

Patahan-patahan circuit line yang ada pada bentukan desain motherboard didesain ulang menjadi suatu kesatuan pada bentukan massa, mengikuti axis tapak yang ada. Massa digambarkan bukan hanya sebagai arsitektur, melainkan sebuah machine. Warna penutup dinding disamakan dengan warna penutup pada motherboard.

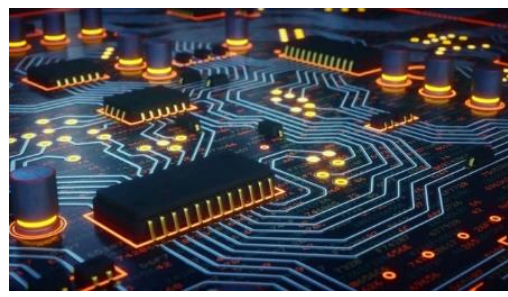

Gambar 27. Circuit board pada motherboard

Sumber : http://www.ipo.gov.tt/types-of-ip/integrated-circuits/

\section{Tipologi}

Berdasarkan studi ruang gerak setiap permainan yang ada, didapatkan beberapa macam tipe bentuk ruang dan perletakan fungsi di dalamnya yang cocok berdasarkan jenis game-nya: 

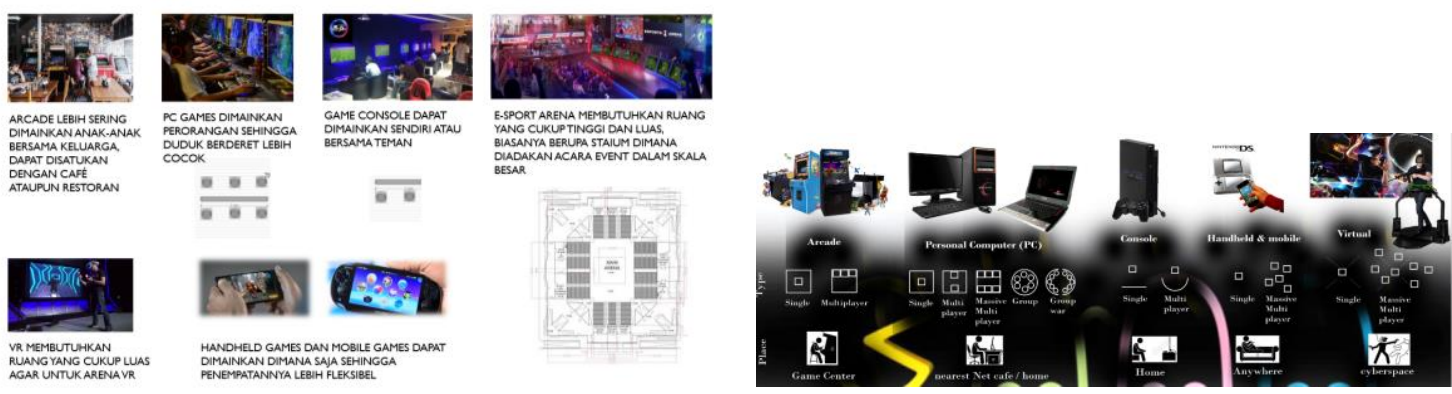

Gambar 28. Pembentukan tipe ruang Sumber: Penulis, 2019

\section{Proses Gubahan Massa}

Berawal dari konsep area motherboard yang dibagi menjadi 2 bagian yaitu, bagian inti dan pelengkap. Maka zona bangunan juga dibagi menjadi 2 bagian; program inti dan event. Hal ini bertujuan untuk memisahkan arus kepadatan pengunjung dan memberikan luasan yang cukup untuk area event. Lalu mulai dibuat penghubung untuk kedua zona yang ada. Pembentukan massa juga mengalami serangakaian penyesuaian terhadap bentuk tapak, kondisi lingkungan tapak, perbedaan ketinggian dan axis bangunan. Ditambah dengan pertimbangan akan konstruksi dan estetika, maka proses pembentukan massa dapat digambarkan seperti gambar di bawah ini :

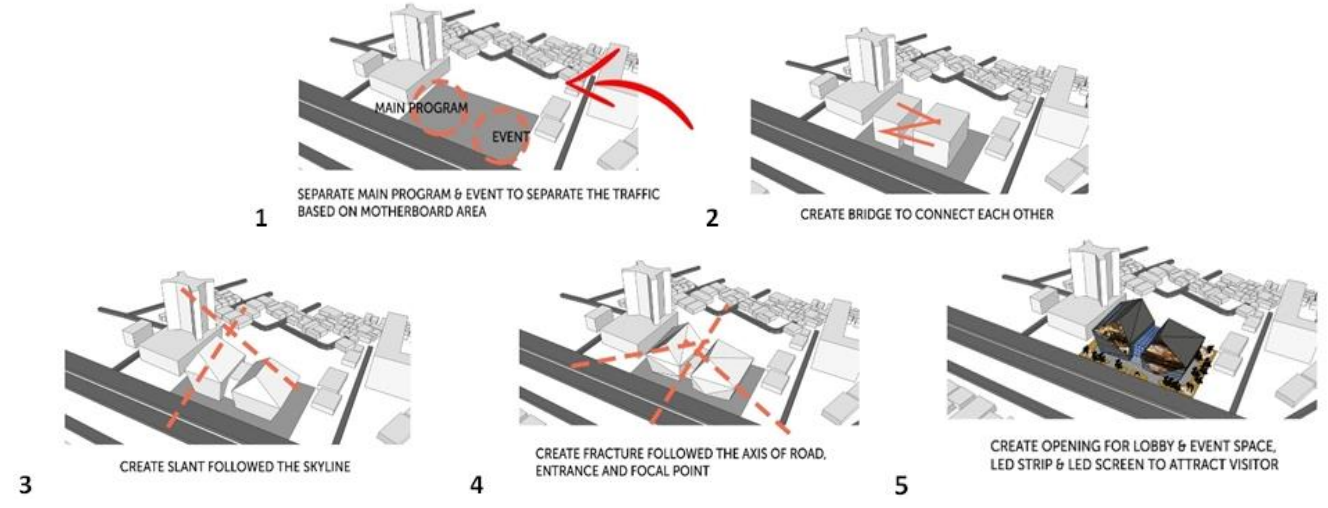

Gambar 29. Proses gubahan massa

Sumber: Penulis, 2019

\section{Hasil Perancangan}

Arena Komunitas gaming didesain sedemikian rupa sehingga dapat merepresentasikan gaming itu sendiri. Ruang gaming biasanya didesain gelap dan tertutup agar cahaya sinar matahari tidak memantul pada layar peralatan elektronik. Untuk itu, dipakailah LED screen pada bagian luar bangunan agar tidak terkesan terlalu tertutup. LED screen juga dapat menjadi daya tarik bangunan yang mengundang masuk peminat gaming. LED screen yang ada menayangkan siaran langsung kejadian dan kompetisi gaming dalam bangunan, sehingga seakan-akan tidak ada batas antara ruang luar dan dalam bangunan. Tema motherboard juga diterapkan pada LED strip dan bentukan patah-patah pada bangunan.

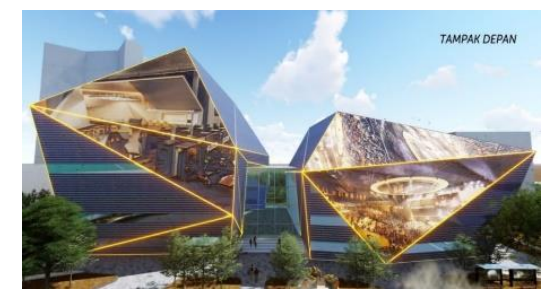

Gambar 30. Tampak depan bangunan

Sumber: Penulis, 2019 
Untuk struktur fasad bangunan menggunakan pipa baja yang dilapisi dengan aluminium sheet sebagai penutupnya. Rangka pipa baja menjadi rangka keseluruhan permukaan fasad sehingga tidak memiliki batas antara atap dan dinding. Sistem untuk mekanikal, elektrikal dan plumbing dibuat seefesien mungkin agar pemasangan pipa lebih mudah dan murah.

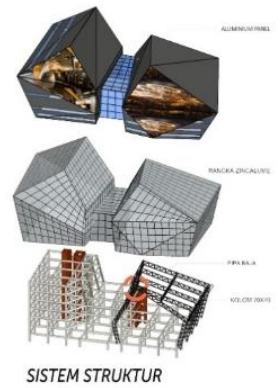

SISTEM STRUKTUR

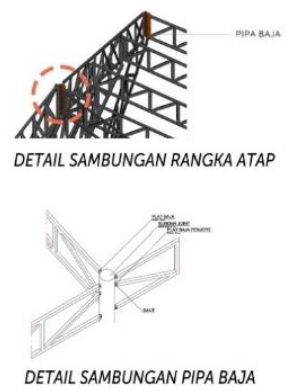

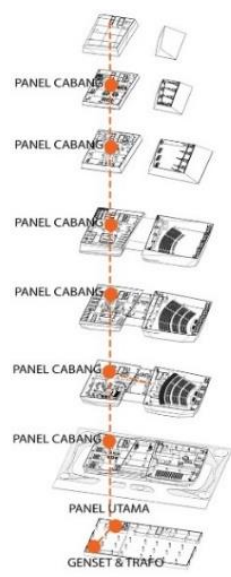

ELECTRICAL

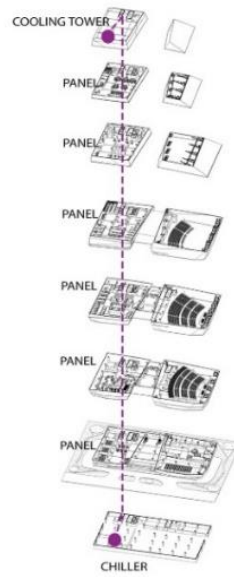

MECHANICAL

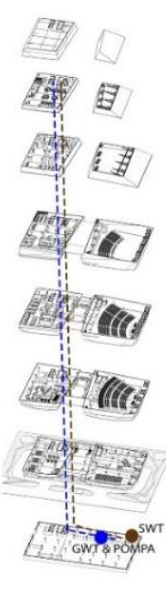

PLUMBING

Gambar 31. Sistem struktur bangunan dan system MEP

Sumber: Penulis, 2019

\section{KESIMPULAN DAN SARAN \\ Kesimpulan}

Terdapat 2 unsur penting dalam gaya hidup masyarakat generasi millennial saat ini, yaitu dunia maya dan hiburan. Generasi millennial yang penat dengan hiru pikuk kehidupan perkotaan seringkali mencari hiburan di dalam dunia maya, salah satunya dengan bermain video game/gaming. Oleh karena itu wadah untuk gaming sangat berpotensi besar untuk berkembang. Diperlukan juga suatu tipe dan tema bangunan yang dapat menggambarkan gaming itu sendiri sehingga menjadi suatu model. Sirkulasi dan pembentukan ruang yang ada nantinya akan membentuk perilaku yang diinginkan. Contohnya saja dengan banyak memberi area berkumpul dan membuat sirkulasi yang terhubung satu sama lain (Mobius) dapat mempererat komunitas yang ada.

\section{Saran}

Gaya hidup dan perilaku Generasi Millenial cenderung mengikuti perkembangan jaman yang ada. Dapat dipahami bahwa tipologi dapat berubah sewaktu-waktu di masa yang akan datang. Sehingga dibutuhkan fleksibilitas desain agar tidak tertinggal oleh perubahan jaman yang ada. Diharapkan laporan perancangan ini dapat memberi manfaat untuk kemajuan perubahan ilmu pengetahuan arsitektur yang ada.

\section{REFERENSI}

Alpwatson, D. (2005). Time Saver Standards for Architectural Design : Technical Data for Professional Practice. New York : McGrawhill Book Company.

Chiara, J. D. (1992). Time Saver Standards for Interior Design and Space Planning. New York: McGrawhill Book Company

Sutanto, A., dan Andani, L. (2018). Dear Millennials, Dialogue Between Type and Behaviour. Jakarta.

Tjahjono, G. (2000). Metode Perancangan Suatu Pengantar Untuk Arsitek dan Perancang. Jakarta: Universitas Indonesia.

https://dictionary.cambridge.org/ 
https://chikhungunya.wordpress.com/2011/05/26/definisi-game-dan-jenis-jenisnya/ http://ratihsubagyo.blogspot.com/2011/01/pengguna-internet-di-indonesia.html https://id.wikipedia.org/wiki/Permainan_daring\#Dampak_Positif

http://www.martinrecords.com/game/penting-untuk-diketahui-sejarah-perkembangan-gamedan-jenisnya/

https://skyrisecities.com/news/2016/09/updated-w-hotel-los-angeles-proposal-features-massivewrap-around-led-screen

https://forbiddenplanet.com/catalog/toys-collectibles/statues-busts/?page=1

https://www.pricebook.co.id/article/review/2016/01/26/3593/ada-4-jenis-dan-11-genre-gameyang-mana-favorit-kamu

https://g2hcombro.wordpress.com/sejarah-perkembangan-game/ https://www.idntimes.com/tech/games/abraham-herdyanto/10-tahap-perkembangansejarah-video-game-dari-era-awal-hingga-sekarang-1/full

https://tekno.kompas.com/read/2014/11/24/07430087/Pengguna.Internet.Indonesia.Nomor.Ena m.Dunia

http://isparmo.web.id/2018/08/01/data-statistik-pengguna-internet-di-indonesia-2017berdasarkan-survey-apjii/

https://kominfo.go.id/content/detail/4286/pengguna-internet-indonesia-nomor-enamdunia/0/sorotan_media

https://www.un.org/sustainabledevelopment/sustainable-development-goals/

http://belajarkreatifhappy.blogspot.com/2018/01/pendahuluan-tipologi-tipe-berasaldari.html https://www.behance.net/gallery/775072/Flux-Game-Center

http://www.esreality.com/?a=post\&id=1176335

https://www.dimsumdaily.hk/asias-biggest-cyber-games-e-sports-stadium-in-mongkok-opens-itsdoors-on-29th-january-to-gaming-enthusiasts/

https://populous.com/our-projects/esports-performance

Https://www.ksat.com/news/tech-sa/tech-sa-port-san-antonio-reveals-plans-for-new-innovationcenter 
